\title{
THE CONCEPT OF "HAPPINESS" IN THE WORKS OF AL-FARABI AND THE RELIGIONS OF ISLAM
}

\author{
${ }^{1} \mathrm{~K}$. Kassymbayev, ${ }^{2}$ Ala Farouq Mahmoud Ibrahim
}

\begin{abstract}
In this article, we will try to study deeply about the concept of "happiness" based on religious concepts in the Arab-Muslim society and to determine the notion of "happiness". Analyzing the foundational and theoretical significance of the concept of "happiness" in Islam, quoting from the texts of the Quran and Hadith, thereby we explained the meaning of "happiness" and its role. Also, the article presents the views of Kazakhstani and Arab-Muslim scholars' about "happiness". We use methods of comparative theoretical research of the "happiness" concept. According to the verses of the Quran and Hadith in Islam, a Muslim must not only learn and practice in this life but also pray to Allah in the hope of achieving endless happiness in his future life. Believers trust in a new life that begins after worldly life, that is, an eternal life, and they believe real-life and infinite happiness will be found only in the future. In religious texts, the eternal soul is happy only with the sounds of eternal happiness. Hereby, a religious person knows that material happiness cannot make him happy totally.

Keywords: Happiness, Concept, Islam, Religion, Quran, Hadith, Arabic, Muslim, Happy, Domestic, Foreign, Scholar.

${ }^{1} \mathrm{Al}-$ Farabi Kazakh National University

${ }^{2}$ Cairo University, Cairo, Egypt

Corresponding Author:

K. Kassymbayev,

Reference to this article:

K. Kassymbayev. The Concept of "Happiness" in the Works of Al-Farabi and the Religions of Islam // Adam alemi.

- 2021. - No. 4 (90).

- P. 133-141.
\end{abstract}

This research has been funded by the Science Committee of the Ministry of Education and Science of the Republic of Kazakhstan (Grant AP08857715).

\section{Әл-Фараби шығармалары мен ислам дініндегі «бақыт» концептісі}

\begin{abstract}
Аннотация. Бұл мақалада, араб-мұсылман қоғамындағы діни түсініктерге негізделген «бақыт» ұғымы жайлы мәліметтерді топтастырып, «бақыт» концептісінің мұсылман қоғамындағы орнын анықтауға талпыныс жасалады. Исламдағы «Бақыт» ұғымының негіздерін және теориялық маңыздылығын талдау барысында Құран мен Хадис мәтініндегі «бақыт» ұғымы, оның қолданысы, отандық және араб-мұсылман ғалымдарының аталған концептіге қатысты ғылыми-теориялық тұжырымдарына талдау жасалады. Исламдағы «бақыт» концептісі туралы салыстырмалы теориялық зерттеу әдістері қолданылады. Ислам дінінде Құран аяттарында келгендей, мұсылман адам осы өмірде білім алып, оған амал етумен қатар, ақыретте «Саъадатул-қусуа» шексіз бақытқа қол жеткізу үшін үміттеніп, Жаратушы Алладан дұға етіп сұрау керектігі баян етіледі. Мүміндер дүниелік өмірінен кейін басталатын жаңа өмірге, яғни мәңгілік өмірге сеніп, шынайы өмір мен шексіз бақыттың тек ақыретте ғана болатынына сенімді. Діни мәтіндерде адамның жаны мәңгілік бақыттың дәмін татумен ғана бақытты деген мағыналар баяндалады. Материалдық бақыт адамды шынайы бақытты ете алмайтыны діни түсініктер аясында тұжырымдалады.
\end{abstract}

Түйін сөздер: бақыт, концепт, ислам, дін, Құран, хадис, араб, мұсылман, бақытты, отандық, шетелдік, ғалым. 


\title{
Концепт «счастье» в произведениях ал-Фараби и религий ислам
}

\begin{abstract}
Аннотация. В этой статье, мы попытаемся глубже изучить что такое концепт «счастье» на основе религиозных концепций в арабо-мусульманском обществе и определить место понятия «счастье» в мусульманском обществе. Анализируя основы и теоретическую значимость понятия «счастье» в исламе, цитируя из текстов Корана и хадисов, тем самым объясняя значение «счастье» и его роль. Также взгляды отечественных и арабомусульманских ученых о «счастье», такие как аль-Фараби, аль-Кинди и т.д. Мы используем методы сравнительного теоретического исследования понятия «счастье». Согласно стихам Корана и хадисов в исламе, мусульманин должен не только учиться и практиковать в этой жизни, но и молиться Аллаху в надежде достичь бесконечного счастья в будущей жизни. Были согласны ученые с этим мнением Верующие верят в новую жизнь, которая начнется после мирской жизни, то есть вечную жизнь, и верят, что настоящая жизнь и бесконечное счастье обретет только в будущем. В религиозных текстах это означает, что вечная душа счастлива только вкусом вечного счастья. Говорится, что религиозный человек знает, что материальное счастье не может сделать человека счастливым.
\end{abstract}

Ключевые слова: счастье, концепт, ислам, религия, Коран, хадис, арабский, мусульманин, счастливый, отечественный, зарубежный, ученый.

\section{Introduction}

Since the early years, humanity has been searching for ways of being happy. Each nation, within the framework of its worldview and religious beliefs, pointed out the way to achieve happiness.

In this article, we will group the information on the concept of "happiness" based on religious beliefs in Arab-Muslim society, and try to determine the role of the taken concept in Muslim society.

If we talk about the Arabic equivalent of the word "happiness" and its meaning in the Arabic language, the word "Sa'ida" (سعد) comes from the word "Sa'a:datum" (سعادة), is used as an alternative word to the concept of happiness in our language. In fact, in the popular dictionary of the Arabic language "Lisan al-Arab" the word "Sa'adatum" means "happiness", "fortune", as the antonym of this word is used in the meaning of "shaka:ua" (شقاوة) "misery", "grievous state". Among the Arab people, there is a saying as: "Yaumun sa'dun ua yaumun nahs" يَوْمْ سَعْدُ وَ يَوْْمٌ نَحْس , which means "One day is joy, one day is sadness" [1, p.214].

In these phrases, the word "joy" is given in the root of the word "sa'dun", to this word "nahsun" was used as an antonym. This means that in any language, the most common synonyms of a word or the significance of a single word associated with its features when using a phrase. This phrase, which came into the dictionary, according to the worldview of Arabs, can be understood as an expression in the language of the fact that everyday life is meant to be happy or unhappy.

In Arab-Muslim society, the main group of people associate the concept of happiness with religious concepts, and in order to calm their spirituality, they associate their happiness with the performance of religious rites. They promptly fulfilled the obligatory and additional acts of Islam as Sunnah and mustahab, turned to piety and sought to earn the approval of Allah, the Creator, as much as possible for their good deeds. A person who truly believes that all good and evil come from the same God, and who fully observes the conditions of faith, can give up what he is unable to do with the Almighty God, and on this basis, he can get rid of his anxiety and helplessness.

The Quran is a holy book for Muslims that describe all aspects of human life and happiness. In the Quran text, the word "sa'ada" ("happiness") occurs only in two places. The first is in verse 105 of the Surah "Hud": "The Day it comes no soul will speak except by His permission. And among them will be the wretched and the prosperous" (11:105) [2, p. 233], here sad 
and happy peoples' conditions have described on the Judgment Day. In the second place, in verse 108 of the Surah "Hud": "And as for those who were [destined to be] prosperous, they will be in Paradise, abiding therein as long as the heavens..." (11:108) [4, p. 233] implies that true happiness is in the "Paradise".

In this regard, every Muslim person associates happiness with entering Paradise in this world. It is believed that a Muslim can only be happy if he escapes from evil and obeys the rules of Sharia. However, one of the Turkish researchers Hasan Yildiz in his study "Kur'an'da mutluluk" ("Happiness in the Quran") said: "It is worth mentioning that the word "sa'ada" found in the text of the Quran has two different meanings. First, happiness in the future life means getting to Paradise, and second, happiness in this world which means enjoying this world and not experiencing any trials $[6, p .7]$.

When "sa'ada" ("happiness") is an antonym to the word "shaka:ua" ("unhappy") in 12th place in the text of the Quran the أشقى، شقيًا، يشقى، شقوا، فتشقى، "words as re found. And if we talk about synonyms of the word "happiness", then the dictionary of al-Ma'ani presents a sequence of words: "فرورد" (farah), (surur), "مرح" (marah), "ابتهاج" (ibtihaj) [AlMa'ani, electronic link]. In the text of the Quran, these words are sometimes used in examples of pronouns, verbs, singular and plural forms. In particular, the word "Farah" have been used 21 times, the word "Surur" 3 times and the word "Marah" 3 times.

\section{Methodology}

The article attempts a comprehensive scientific analysis of the concept of "happiness" in Islam. Comparative theoretical research methods are used as a scientific tool. In addition, in the course of the research, in the works of foreign and domestic authors-researchers, as a scientific basis and source, opinions related to the topic set out in the works of foreign and domestic authors will be presented. The analysis of texts is carried out by hermeneutical and comparative, stylistic research methods.

\section{The Main Part Importance of the Concept of «Happiness» in the Hadith Texts}

Previously, when Islamic scholars described religion, they said that religion is a divine law that shows people the way to happiness and how they will achieve happiness. Therefore, according to Islamic scholars, to be happy, you need to follow the instructions of religion. Because Islam is based on personal happiness. As mentioned above, the word "happiness" occurs only in two verses of the Quran, but in other verses, it means that a person who "runs away from the fire of hell, goes straight", and then enters Paradise and resides in the gardens of Paradise, has achieved infinite happiness $[9$, p. 5].

In Islam, the hadith of the prophet Muhammad, which is the second source after the Quran, gives the concept of "happiness". For example, there is a hadith about it: "One reason for happiness is obedience to God's judgment. And the misfortune of a person is that he does not want to stop asking Allah for goodness and dissatisfaction with the order of Allah" [10, p. 15].

In the hadiths, the concept of "happiness" is given in Arabic in a few words. Including:

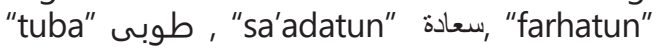

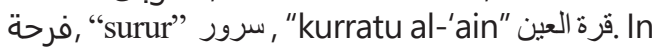
the hadith from Anas Ibn Malik:

طوبى لمن آمن بي و أراني و طوبى لمن آمن بي و لمني and believe in me, and how happy are those who do not see me and believe in $m e^{\prime \prime}[11$, p.124] hadith of the Prophet Muhammad (peace and blessings of Allaah be upon him).

When people are in the womb, they are created with the potential for happiness and unhappiness. Due to their desires and 
actions in life, a person can be happy and unhappy. In the following cases:

In one of the hadiths of the Prophet Muhammad related to Sa'd Ibn Abu-Uakkas about fortune and happiness: من سعادة ابن آدم رضاه بما قضى الله له

"A person who is satisfied with the commandments of Allah will be happy" $[11$, p. 166]. Therefore, we gladly obey the commandments of the Creator and are satisfied with them.

The question of who will receive the mercy of the Prophet on the Day of Judgment is conveyed from Abu Huraira:

أسعد الناس بشفاعتي يوم القيامة من قال لا إله إلا الله خالصا من قلبه أو نفسه

"On the Day of Judgement is considered the happiest person with my applause, a person who has accepted God other than Allah" [12, p. 373]. Here the phrase "the happiest" informs everyone who will be happy with the applause, and it is described in detail that in this context, that this very person is the happiest one. In order to alleviate difficulties, one of the ways presented to achieve happiness is to say the words of Istighfar, asking for forgiveness from Allah.

In this regard, in the hadith conveyed from Abdullah Ibn Abbas, the Prophet Muhammad (peace and blessings of Allaah be upon him) said:

طوبى لمن وجد في صحيفته استغفار ا كثير ا

"What a happy man found in his book of deeds that he asked for forgiveness" $[15$, p. 134]. This hadith is about istighfar and asking for forgiveness from Allah.

And if you ponder over the above-mentioned hadiths of the Prophet Muhammad to achieve "happiness", however, caused a lot to be happy. The purpose of the hadith is the mercy of Allah, the applause of the Prophet, and the entry into Paradise with the help of them. However, the readiness of humanity reaches happiness by following orders written in religious texts. A person with high moral qualities, a person who tries to improve it, achieving happiness, determines the maturity of life.

\section{Determination the Notion of \\ "Happiness" in the Arab-Muslim Society}

Such ethical ideas can be seen in the works of medieval thinkers such as alFarabi, Yusuf Balasagun, Ahmet Yugineki, Ahmet Yasavi, and others. In the works of these scientists, «happiness» is described as a question of knowledge, justice, and morality. Islamic values and moral issues are considered as a single world.

From the teachings of medieval thinkers, it is clear that improving the virtues of kindness, love, patience, tolerance, etc. mentioned in the Quran leads to the understanding of truth as happiness. That is, through Islam, everyone can pray to God, listen to what is written in the Quran, and find happiness through them.

Happiness is a state based on human emotions, which is not measured by large or small, but, on the contrary, is measured by whether a person reaches a certain goal or not, whether it is achieved or not.

What is happiness in any nation? Does it have a moral value, a certain dimension? It is true that there are many different answers to these questions. However, humanity is largely dependent on the money they earn, the mansions they build, the modern vehicles they carry, and so on. Comparatively, people classify themselves as happy or unhappy.

According to Islam, to live well, you need to have faith. All Muslims should believe in the foundations of the Islamic faith (faith in the unity of God, faith in the resurrection, etc.) [19, p.92-100]. Islam covers all aspects of life (personal, spiritual, economic, social, political, and family). Therefore, Muslims believe that religion is inseparable from all aspects of life.

Our ancestor al-Farabi also wrote treatises on happiness in Islam. In particular, this is closely related to the ethical and socio-political issues raised in other works, such as "On achieving happiness", "Views of respectable citizens", "Civil policy", "Guide 
to happiness". The great philosopher of the East, Abu Nasir al-Farabi, was the first who systematically consider happiness. Al-Farabi in his book "The Views of the People of a Good City" (al-MadinatulFadila) defines happiness as "achieving competence without material needs". In his work "Guide to happiness" (Risalatu at-Tanbih ala-Sabili al-Sa'ada), he gives a comprehensive understanding of the main goal of every person in life is - happiness [23, p.177]. According to him, people are mistaken for determining true happiness. Sometimes he sees wealth, sometimes he sees something else as happiness and calls for a deeper understanding of its meaning.

According to al-Farabi, a spiritual understanding of human actions and behavior are very important in the pursuit of happiness, because it is a socially important action, not only in how a person acts following their desires but also in receiving praise or shame in society. Natural action associated with the stress of the human soul is not enough to achieve happiness. It is not enough to want to do something good and bright. For a person to be sure that their actions are transparent, the correctness of their actions must be recognized by society. Therefore, says the thinker, "we must determine what our actions are right, what our emotions should be, what our activities should be to achieve a good mind" [24, p. 328].

The problem of happiness arose from personal development and the study of socio-cultural relations. Al-Farabi develops a concept that avoids focusing on the individualistic-egoistic ethics of sociocultural relations. It is aimed at forming a spiritual worldview that confirms life, rather than modern ideas aimed at "harmonious living" of virtual city residents, pessimism, flight and departure from socio-cultural life [24, p. 89].

There are good and bad qualities in a person. His abilities can be applied to both good and bad cases. At the same time, respect for the virtues of love, honesty, justice, and truthfulness emphasizes the need to adapt your abilities to the best side.

Al-Farabi in his book "Civil politics" states that "a person in any situation understands happiness only by the power of the theoretical mind, and not by any other power". This is a practical action when a person uses and understands the first initiatives and initial knowledge that give a person a sound mind, and then when he seeks to find a path to happiness through practical efforts. Then seeking power executes the actions received through the power of thought. The power of imagination and comprehension develops and helps the power of reason, leads to actions that create the conditions for a person to achieve happiness, and then the person will benefit. Thus, he will achieve prosperity through his power [25, p.130].

Evil, as we have considered in the form of a clear understanding of its purpose when it is described as happiness by the power of reason. When a person does not understand what happiness is, he openly strives for it and pursues something other than the goal of a happy life: profit or fame. He strives to achieve what drives him. He figured out how to achieve this goal. This is done with the help of an aspiring force. Thus absolute evil will take place in our lives.

Al-Farabi states that people will have common qualities and that they have the qualities that are unique to them. All these natural qualities are based on willpower, which must be developed, showing that each person has their unique peculiarities. According to al-Farabi, if they are neglected and not developed in practical terms if they are not used for other useful activities and if they waste time, these qualities will disappear.

The good qualities inherent in the human body will disappear without a certain practice, without its development, without a clear direction; he explained that the scientist understands that the only effective result is the ability to recognize the quali- 
ties of a person. A person's ability to distinguish from nature what he or she deserves, his or her propensity for certain behaviours, his or her immaturity, and his or her ability to adapt to the behaviour that he or she is prone to. He believes that only a self-aware generation can be a step towards humanity.

"A person who can achieve results in any field will be the leader of people who does not have such abilities. This does not give a positive result. People who are more able to achieve results will be happy, and people who can achieve results will be happier, and positive results will not be achieved" [26, p. 22-23].

Al-Farabi knew the verses of the Quran excellently and fully understood their meanings. As a result of this understanding, all aspects of the system are based on the basic principles of Islam. Thus, the al-Farabi system freed mankind from backwardness and primitiveness and paved the way for the happiness and scientific achievements of those who have moral qualities [27, p. 32].

Although happiness is one of the most important issues of human life, the concept of happiness is still ambiguous. People understand happiness in different ways; happiness is wealth, career, strength, and others can also be. Although these factors mean happiness, however, happiness is not limited to these factors. Islam argues that happiness does not arise from any of these factors [18, p. 179-194].

Happiness is a human tendency toward which people always strive and never give up [24, p. 297]. The pivotal thing in the history of mankind to achieve happiness is a waste of purpose and effort.

All reflection and research, in order to understand the meaning and purpose of life, ultimately leads to "How to achieve happiness?" The answers to these questions are being studied.

\section{Discussion}

Almost all the thought systems that appeared in history expressed their opinion about happiness. They also tried to determine the nature of happiness and the ways to achieve it. Many philosophical schools that express a direct or indirect idea of happiness are understood as the ultimate goal of a happy person. Having studied philosophical concepts to the concept of happiness, they told their thoughts. For example, the moral philosopher, especially the concept of happiness, has been extensively studied by the ancient Greek philosophers [19, p. 2]. The concept of happiness, which philosophers perceive in various ways, shows that the main problem of Greek-moral philosophy and morality in Greek philosophy has an "edaimonistic" character. From ancient Greek philosophers to Democritus (fourth century $\mathrm{BC}$ ), the idea that happiness is the ultimate goal of human behaviour took various forms in the history of philosophy. In these various forms, the concept of happiness sometimes takes the form of hedonism, sometimes it is determined by virtues, sometimes it is pragmatic, and sometimes it is realized through experience and experimentation [8, p. 21]. Among the ancient Greek philosophers, Platon and Aristotel more or less distorted Islamic philosophers in terms of moral understanding. This influence revealed not only their moral understanding but also their attitude to happiness and nature.

According to Yusuf ibn Ishaq al-Kindi, the first Islamic philosopher: "The path to good lies through the prohibition of lust and desires. Because how to give everything does not lead to good. Al-Kindi said that things that are considered unpleasant and tastes that are pleasant to our senses interfere with the use of the mind [16, p.71].

Since the goal of a person is to achieve the highest happiness, a person must know what happiness is and be instructed in what to do to achieve it. Ibrahim bin Hamd Al-Qa'id in his book "An Individual Guide to Happiness" states: "Happiness" is a psychological state of pleasure, satisfaction created by God, and an indicator of a person's relationship with the Lord that lasts a lifetime" [17, p. 37].

The Egyptian writer and linguist Muhammad Ahmad Zhad al-Maula in his 
book "Al-Halk al-Qamil" says: "Happiness is peace of mind, that is, purity of heart and a living conscience". And in the same work, he says: "Happiness is satisfaction, and satisfaction is happiness" [11, p. 229].

The Persian philosopher Abu Ali Ahmed ibn Miskawaih described happiness as "the sweetest, highest, most precious and purest of all". It is very simple, different from the feelings and pleasures of animals. He argued that the highest happiness can only be achieved through knowledge and wisdom and that the highest happiness can be gained by achieving death for the Creator [29, p. 105107].

According to Ghazali, in order for the goal to be good, it must be not only fragrant and beautiful but also useful. If the action includes all three, there is no absolute happiness. On the other hand, the ultimate goal of all good deeds and the greatest unity that all good deeds are aimed at is happiness in the hereafter. Ghazali, like other Islamic philosophers, argued that science and wisdom are superior to all other pleasures. According to him, pleasure from the mind gives the greatest happiness. The main happiness is spiritual happiness [30, p. 340]. Such happiness can only be achieved through divine truth.

\section{Conclusion}

Happiness in this world and in the future is closely related. Indeed, the belief that all heavenly religions were sent to secure this world and the future is reflected in the holy books. At the same time, followers of religions are advocating this issue, which reinforces the close connection between happiness in both lives.

This is the pleasure that a person receives in life, according to philosophers, "relative happiness". If the so-called world of absolute and relative happiness does not lead to happiness in a future life, it is classified as a deceptive and temporary form of relative happiness [2, p.109-110]. If there is a character who brings happiness to a future life, then happiness becomes its absolute glory. And this shows us that happiness surrounds the world and the afterlife. Future life, which means a second life, which begins after this worldly life and lasts forever, occurs in more than 110 places of the Quran in various forms.

Believers believe in a new life that begins after the worldly life. Since this is eternal life, they are convinced that the real-life will come only in the future. Because the eternal soul is happy only from the taste of eternal happiness. Material happiness cannot make the soul happy, because they are not far from being temporary.

The Quran tells us that the existence of the world is temporary and a test for the creation of the universe and the sending of man to earth. People are not in vain in this life, they turn to the divine messages sent through the Prophets to find the right path and achieve eternal happiness. Divine messages help a person to act in accordance with their pure nature and sometimes stay on the right path.

The only cause of happiness or unhappiness in the future will be the balance of things done in this world. The most important thing in achieving happiness in the future is the result of work done in this world. For this reason, "knowledge" that is, information about the existence, appears first in the future. In this regard, Abu Hamid al-Ghazali said: "All that people have long wanted is happiness, knowledge and action," so this clearly demonstrates the superiority of science [13, p. 236].

Happiness in the future can only be achieved by combining knowledge with action. Since the action is the experience of science, practice is one step ahead of science, but we must not forget that science is the first step. Science is a theory of happiness, and action is its experience. The knowledge gained through curiosity and reflection shows people the path to happiness and the ability to create it, and also play a leading role in practice [22, p. 72].

The only living creature that can achieve 
happiness in this world and in the future is a person with an artistic character [5, p. 59]. Because of this quality, it is recommended to pray for him in order to give "Hassanat" (goodness) both in this world and in the future.

The actions taken in this world are very important. To enter Paradise and be happy, we must avoid the main sins forbidden by Sharia. Some of the main sins are theft, rebellion against parents, adultery, bribery, gossip, usury and extortion. If these great sins were committed in this life, they would be unhappy in a future life and would not be able to enter the Paradise Gardens. As a result, as stated in the verses of the Quran in Islam, a Muslim must not only learn and practice in this life but also pray to Allah in the hope of achieving endless happiness in future life.

Thus, we made a brief analysis of the concept of "happiness" in the Quran and the hadiths of the Prophet Muhammad.

The scientist who studied the word "happiness" from Islamic sources before we state the only factor of happiness is a person's life and experience, a person is a source of happiness.

\section{References}

1 AbdrahmanovaA.K. Rol' zhenshhiny v kazahskom tradicionno obshhestve [The role of women in Kazakh traditional society]. Mater. mezhdunar. nauchn. konf. "Rol' zhenshhiny v razvitii sovremennoj nauki i obrazovanija» Minsk: Belorusskij gosudarstvennyj universitet, 2016. - pp. 250-253.

2 Chepeleva A.V. Zhenshchiny $v$ sufizme. Eticheskiy aspekt filosofii lyubvi [Women in Sufism. The ethical aspect of the philosophy of love]. Avtoreferat dissertatsii na soiskaniye uchenoy stepeni kandidata filosofskikh nauk. Sankt-Peterburgskiy gosudarstvennyy universitet. -2016 . -15 p.

3 Saba Mahmood. Politics of Piety. The Islamic Revival and the Feminist Subject. - 2005. - pp. 216-245.

4 Avishai, Orit. «Doing Religion» in a Secular World. Women in Conservative Religions and the Question of Agency. University of California. Berkeley. Gender and Society. - 2008. - pp. 1238.

\section{$140 \mid$ АДАМ ӘЛЕМІ

5 Koran. Perevod i kommentarii I. YU. Krachkovskogo. Pod redaktsiyey V.I. Belyayeva. Izd. 2-ye. M. Glavnaya redaktsiya vostochnoy literatury izdatel'stva «Nauka». - 1986. -727 p.

6 Knysh A.D. Musul'manskiy mistitsizm: kratkaya istoriya [Islamic Mysticism - A Short History] Knysh A. D. per. S angl. Romanov M. G. - SPb.: Izdatel'stvo «DILYA», 2004. - 464 p.

7 International Association of Sufism. [Elektronic resource] (date of the application: 24.04.2020). http://ias.org/buildingbridges/

8 University of Sufism and modern sciences. [Elektronic resource] (date of the application: 09.04.2020). https://www.usms.edu.pk/.

9 Sobraniye fetv po obosnovaniyu zikra dzhakhr i sama' [Collection of fatwas on the substantiation of dhikr dzhakhr i sama']. Sost.: B.M. Babadzhanov, S.A. Mukhammadaminov; otv. red. Muminov A.K. Dayk-Press. Almaty. 2008. - 312 p.

10 Temirbayeva A., Smagulov M., Temirbayev T. Sufiyskiye obrazovatel'nyye praktiki $\mathrm{V}$ sovremennom Kazakhstane: proshloye i nastoyashcheye [Sufi educational practices in modern Kazakhstan: past and present]. Adam alemi. 2019. N 4. - pp.112-117.

11 Ofitsial'nyy YouTube kanal Khazireti Kurbanali Akhmed Ishan. [Elektronic resource] (date of the application: (04.11.2020). https:// cutt.ly/ggDqhOc

12 Etnokul'turnyye tsentry Assamblei naroda Kazakhstana: vzaimodeystviye etnicheskogo i religioznogo $v$ svetskom obshchestve: monografiya [Ethnocultural Centers of the Assembly of the People of Kazakhstan: Interaction of Ethnic and Religious in a Secular Society: Monograph]. D.N.Nurmanbetova, R.I.Kamarova, T.A.Lipina, K.Tyshkhan, YU.V.Shapoval, A.YU.Antipin, G.T.Kamarova, G.SH.Asylbekova. - Astana: TOO «Master Po», 2017. - 197 p.

13 Isayev E. Uvazheniye k chechenskoy zhenshchine [Respect for human life]. [Elektronic resource] (date of the application: 04.11.2020). https://nohchalla.com/obychai-i-tradicii/859uvajenie-k-chechenskoy-jenshine

14 Temirbayeva A. Novyye religioznyye konstrukty sufiyskikh praktikv Kazakhstane [New religious constructs in modern Kazakhstan]. Mater. mezhd.nauch.konf. «EurasiaScience». Moskva, 2017. - pp.129-130.

15 Sinyakov O.V. Ob informatsionnoraz"yasnitel'noy rabote $v$ sfere religii $v$ SeveroKazakhstanskoy oblasti [About outreach work 
in the field of religion in the North Kazakhstan region]. Materialy onlayn kruglogo stola 29.10.2020. [Elektronic resource] (date of the application: 04.11.2020). http://religionscongress.org/ru/news/novosti/567

16 Pro lysogo Ablyazova i lysykh glupykh zhenshchin [About bald Ablyazov and bald stupid women] [Elektronic resource] (date of the application: 04.11.2020) https://www.youtube. com/watch?v=Ary8IL1jPBw\&feature=youtu.be.

$17 \mathrm{~V}$ Tatarstane prizyvayut Erdogana zashchitit' musul'man ot vlastey RF [Tatarstan calls on Erdogan to protect Muslims from the authorities of the RF] [Elektronic resource] (date of the application: 04.11.2020). https://www. youtube.com/watch? $v=4$ NOMHVBJLQs\&featur e=youtu.be

18 Vse taki zhiv v kazashkakh - dukh voina!
[Still, the spirit of a warrior is alive in Kazakh women!] [Elektronic resource] (date of the application: 04.11.2020). https://www.youtube. com/watch?v=ZvjcN0A4F6s\&feature=youtu.be

19 Smagulov M.N., Dosmaganbetova A.A., Seytakhmetova N.L., Sartayeva R.S., Sagikyzy A. Institutionalization of islamic education in the kazakhstani secular society. European Journal of Science and Theology. №14 (2018). - pp. 65-75.

20 Moldagaliyev B. Ye., Smagulov M., Satershinov B.M., Sagikyzy A. Synthesis of traditional and Islamic values in Kazakhstan. European Journal of Science and Theology. № 5 (2015). - pp. 217-229.

21 Temirbayeva A. et al. Sufi practices in modern Kazakhstan: traditions and innovations. Central Asia and the Caucasus. № 24 (2021). pp. 91-98.

\section{INFORMATION ABOUT AUTHORS}

Kuanysh Kassymbayev

Ala Farouq Mahmoud Ibrahim

қуаныш Жанаталапұлы Қасымбаев

Ала Фарух Махмуд Ибрагим

Куаныш Жанаталапович Касымбаев

Ала Фарух Махмуд Ибрагим
PhD student, Al-Farabi Kazakh National University, Almaty, Kazakhstan, kuanishnm@mail.ru

Professor, Cairo University, Cairo, Egypt

PhD докторант, Әл-Фараби атындағы Қазақ ұлттық университеті, Алматы, Қазақстан, kuanishnm@mail. $\mathrm{ru}$

Профессор, Каир университеті, Каир, Египет

$\mathrm{PhD}$ докторант, Казахский национальный университет имени аль-Фараби, Алматы, Казахстан, kuanishnm@mail.ru

Профессор, Каирский университет, Каир, Египет 